\title{
Development and Subsidization Possibilities for Efficient Energy Provision in the Hungarian Built Environment Within the 2021-2030 EU Programming Period
}

\author{
Maria Borocz \\ Climate Change Economics Research Centre, Szent István University, Gödöllö, Hungary \\ E-mail: böröcz.maria@gtk.szie.hu
}

\begin{abstract}
The NER300 program, founded by the European Commission, is one of the world's largest initiatives for funding low-carbon innovation projects like renewable energy development or carbon capture and storage. During the operation of this program there has been 38 supported projects from more than 2 billion Euros. The European Union announced that they are willing to maintain this mechanism for the next programming period from 2021 to 2030 on the name "NER400". According to the early estimations the available amount of funds is going to cover more than 9 billion EUR for the member states. The trend for smart metering systems throughout Europe is well-known among the countries. Still, considering the foreseeable EU regulations regarding the dissemination of these devices. The present study provides with a review of the European best practices for setting smart metering systems and studies the recent Hungarian endeavors for running pilot projects in this field.
\end{abstract}

Keywords: building energizing, smart metering, NER300, NER400, climate policy

\section{INTRODUCTION}

The NER300 development structure made to aid national decarbonisation goals will remain between 2020 and 2030, which will help member states' projects with an increased budget, renamed to NER400 - in other words, an annual 400 million EUA value of subsidy. In Hungary's case, these resources mean development opportunities that amount to several hundreds of millions of Hungarian Forint, if the proper projects can be shown for the given goal system. Hungary already had a decisive success with the "Dél-Alföldi EGS Erömü" project in the first NER 300 period, which brought in 39,3 million Euros (11,3 billion Forint) subsidy from the European Union [1]. The goal of the project was to install an electric power plant on an increased efficiency geothermal system (Enhanced Geothermal System - EGS), which is capable of producing electric energy using the heat of the earth's crust. Its operation is based on the so-called HDR (Hot Dry Rock) technology, during which water is pumped into the crystallized minerals below the ground, until it heats completely due to the heat exposure, and becomes adequate to generate energy from (Los Alamos National Laboratory). The key to its secret is to find high-temperature, homogenous and solid rock [2]. The prior goals of the project were to add the power plant to be built to the national energy demand's satisfaction, increase the region's competitiveness, and naturally, to help Hungary complete the obligations 
it accepted until 2020. The Union's resources allocated for this will cover one third of all costs. Regarding the story of success this would bring to Hungary, we can say that this complex will be the world's biggest EGS power plant after its completion in 2016. The operation is currently one of NER300's supported thermal energy projects which only amount to three, next to the French GEOSTRAS and the Croatian Geothermae projects. Taking the future into consideration, this also signifies Hungary's important position and potential related to using geothermal energy, which will definitely be a worthy basis for the NER 400 period. Prior analyses suggest that the amounts that can be queried from the next subsidy fund, increasing to four times their previous size, will favour such high resource-intensive projects.

\section{Implementing "Smart Metering", and creating a basis for "Smart Grid" systems}

Though analysing the attributes of the NER300 system would be too soon, since its implemented projects are still in their execution period, we might find it worthwhile to look at programmes and trends in the world, most notably in Europe [3]. The financing goals of NER400 are also unknown at present, but will probably advocate wind-, thermal-, bio-, solar- and ocean-energy similarly to its predecessor, among all renewable energy resourcebased developments. However, beyond these, most notably in the last decade in Europe, we could see a trend which not even Hungary reacted adequately to, furthermore, only three such programmes began within the framework of NER300. And this is none other than the "Smart Metering". Choosing among the listed alternative energy resources and their personal preference is obviously a government decision, and is subject to the influence of capacities one country might have. Hungary has such capacities for thermal energy utilisation, northern countries for wind- and ocean-energy, while southern ones for solar systems. Smart Metering, however, isn't one method of energy extraction, but a new and innovative form of its usage, which many consider to be the new evolutionary stepping stone of energy management

The essence of Smart Metering is that it serves real-time information about the electric energy consumption, and serves it both to the consumer, and the energy service provider. Its advantage is that it paints a particularly precise picture about the trend of energy consumption, thanks to which the consumer also becomes able to optimise his/her energy consumption, based on when he/she can procure it at the lowest possible cost. During this, the service provider can more simply detect illegal usage, and may even have the opportunity to intervene for economic optimisation using the consumption trends they saw over time [4]. Many confuse this with the so-called "Smart Grid", otherwise known as intelligent systems, which only include Smart Metering as an element. If Smart Metering itself doesn't, Smart Grid's idea does reach a next evolutionary stage, since this system can manage a house's, block's, larger geological unit's electric system on its own, going far beyond simple measurements and economic decisions based on them. A rather utopia-like, but close plan of some countries is that each of their consumers operate smart measurement units in their household not only for electricity, but for water- and gas systems as well. After this, any tools, computers, tablets or even a simple phone can be used by the consumer to follow his/her own consumption, and modify it according to economic perspectives. Each user is linked to each other, and personal systems send signals into larger distribution stations, showing consumption, thereby regulating their operations, and tailoring it to actual demands. Thanks to this, there's no excess payment, or wasted energy. Furthermore, these mechanisms are capable of foreseeing electric power shortages, resetting the systems and utilising the high-rate connection network, switch to other servicing units if necessary before the shortage goes live [5]. 


\section{DISCUSSION}

When talking about the described intelligent technological solutions, we have to note that while in Europe's southern region, multiple countries have substantial smart measurement networks, and more developed western and northern countries are already planning the Smart Grid systems based on this, Central Europe shows they lag behind in comparison.

\subsection{European best practices for the utilisation of Smart Metering systems}

Understanding the importance of such development projects, the European Union already took important regulatory measures in their Third Energy Package to advocate them, and help creating these systems to decrease emission rates [6,7]. The EU made it a goal that by 2020 , each member state (where it's an economically sound decision to do so) has to supply at least $80 \%$ of their electric- and gas-consumers with these Smart Metering systems. The self-made cost-benefit analyses served as a basis for countries to help measure economic background, and if they were positive, the measurement systems in question were enforced to be implemented [8]. The European Union offered subsidies related to such research and projects through the Seventh Framework Programme. This is how the "Meter-ON" report of the European Commission was made, originally running between 2012 and 2014, in which they offered an overview of the member states' projects, and their commitment by the 2020 goals. The highprofile research summarised all countries' cost-benefit analyses for introducing smart meters both for electric energy consumers and gas consumers. Its final results were that most of the countries accepted the obligation of redesigning the entire country's electric systems, and in case where negative results were gained from the economic analysis, some level of developments for select clientele was conducted. Apart from the very few countries where the effects of the changes are still being researched, only four countries refused the implementation completely: the Czech Republic, Lithuania, Belgium and Hungary. Apart from them, Portugal also said no to this option, since their research didn't serve precise results, but they assured the Union that they will re-calculate their existing payoff numbers annually. As for gas consumption, the picture is more negative, since few countries would benefit from a national development, which is why more member states refused to implement them [9].

Another similar research analysis of the European Commission reveals that the prior analyses say nearly 200 million smart meters will be installed for electricity across Europe by 2020 , and 45 million others for gas consumption, the cost of which will amount to 45 billion Euros. Therefore, $72 \%$ of electric energy consumers and $40 \%$ or gas consumers will be using these machines across the EU [10]. These numbers and the obligations accepted by the countries clearly show that our country will be a significant portion of the remainder, using out-of-date technological solutions after 2020. And this fact makes it necessary for the next period's development strategies to invest in this area. An even more important perspective is that according to what's been said before, smart measurement is simply the first step to constructing intelligent systems, which many consider to be the determining factor in future development routes. This means that countries which don't construct their basis as soon as possible will be stuck in a competitive disadvantage compared to their partners. In the following part, let's take a look at some European examples on how such projects have to be actualised. 


\subsection{The next example will be the "Telegestore" project, as Europe's best practice}

The Italian electricity service provider named Enel Distribution tested automatic measurement systems in the 90's already (Automated Meter Management), but during their pilot program realisation, they proved to be economically disadvantageous. However, they didn't give up their goals, and committed long research periods, studied American examples, and finally introduced a new plan made in 1998, which was set to actualise from 2001. The project they christened "Telegestore" guaranteed that all Italian household measurement devices, and those of smaller enterprises will be changed to state-of-the-art ones. In less than five years, by 2006, their initiative became the world's biggest AMM project, in which more than 7000 workplaces were made, and more than 32 million measurement devices were installed (20000 measurement device daily). The program's total costs amounted to 2,1 billion Euros, thanks to which $95 \%$ of Italian households have modern devices installed by now. The process' success was measurable both on micro- and macro-levels, and brought huge changes in the Italian electric energy service providing system. While only $20 \%$ of the populace could chose their electric energy provider in 1999, almost everyone can freely choose today. If we take a look at hierarchy, the Enel Corporation stands at the top as a huge distribution organisation, above the mid-sized organisations of larger cities, and smaller municipal distributors. The advantages of the project can be summarised as follows [11].

Consumers' advantages:

- Billing based on actual consumption,

- More advantageous pricing,

- Easier administration,

- Saving on bills.

Advantages the energy sector has:

- More efficient energy supply and lower carbon-dioxide emission,

- Equalisation of "Consumer highs"

- Decreasing trade and technical losses.

Advantages of Enel:

- Leading market position,

- Increasing consumers' satisfaction,

- Decrease in operational costs.

Thanks to the system that was implemented, operational costs were decreased by $40 \%$ between 2001 and 2011, and the quality of the service improved by $68 \%$, measurable via electricity shortages in hours. The average lifetime of measurement devices is 15 years, their error percentage is minimal, $0,3 \%$ annually. We already referred to how consumers have the option of using energy required by them in a more efficient manner due to the more understandable smart measurement systems, meaning how they can optimise its usage. In 2008, merely two years after the Telegestore project was concluded, Italy held an opinion poll among its citizens, which was attended by thousands of Italians from more than 50 settlements. The effects on energy consumers' behaviour are as follows [11]:

- $29,3 \%$ of household machines were used in the evening hours instead,

- Alternative utilisation of household machines increased by $11,9 \%$,

- Turning off electronic machines instead of 'sleep mode' increased by $7,5 \%$,

- Usage of household machines decreased by $6,6 \%$. 
After all this, we can say that the Telegestore project became a fine example of innovative changes that may even cover an entire nation. Outside of Italy, only one European country, namely Sweden realised a Smart Metering solution spanning the entire country at the moment, where $99 \%$ of energy consumers have smart measurement devices installed. They recorded that all energy consumers have to be supplied these devices in the state legislation, in order to make billing more punctual using these machines. Contrary to the Italians, they didn't realise this during a huge overall project, but with multiple programmes instead, reaching national coverage. The leading state electricity service provider, Vattenfall documents an annual 8 million Euro profit since the development, resulting from the new system's efficiency, and the eliminated costs it causes [12].

\subsection{In search of the best: the "Endesa" project, successor to Telegestore}

The Endesa Company is Spain's most notable electric energy service provider, which has $92 \%$ of its shares in the possession of Enel. Therefore, it's no coincidence that after the previously evaluated Telegestore project, which is the largest Smart Metering programme in Europe ever to be finished, the project currently underway was also initiated by them [13]. Its actualisation doesn't only put basis on its predecessor's successes, but on the further developed system as well, since the Enel and Endesa companies cooperated to create a more advanced, much more delicate technology, the so-called "Meters and More" protocol [14]. This is based on three main policies, which are efficiency, robustness and communication safety. Its point is that a much bigger, less sensitively connected system is made, which operates with an updated software and a frequency different from that of previous ones, flexibly providing two-way data communications. The inventor companies also made an association in Brussels, offering free membership access, also called "Meters and More". The goal is to make information related to Smart Metering systems, and their development flow even smoother. Furthermore, they own the rights to apply the technological certificate they designed and elevated into a brand on devices. Today, their association has 40 more members.

About the project itself, it's nice to know that it was accepted in May 2009, to realise the system they envisioned. The first measurement device was installed in June 2010. According to their plans, they'll install 13 million devices in 2015, which will cover the clientele of Endesa. Furthermore, they also realised the importance of Smart Grid initiatives, which is why they consider this program to be more of a stepping stone for intelligent systems, and the project itself was designed to offer the opportunity of actualising such development initiatives in the future [15]. Thanks to this, Spain already saw the completion of Malaga, as the concept of one of the first smart cities (Smart City Malaga). The project may serve as a model for rural development based on sustainable energy resources, even in Africa [16]. And as for Enel's inner workings, we have to note that though not many countries decided to design smart systems in Central- and Eastern-Europe, the Romanian government wants to introduce them by all means, and according to their prior plans, they want to cover their entire country with the technology by 2022 . Since the Italian company holds stakes in Romania as well, they already accepted the task of installing 2,6 million smart devices. This serves for Hungary as both a reminder of taking measures against lagging behind, and as a good example of how such projects can be actualised in this region. After these examples, let's take a look at the conclusions of early Hungarian initiatives. 


\subsection{Hungarian test of Smart Metering (Smart Synergy project)}

Though our country can be said to be in the initial stage of smart metering when compared to previous example projects, its importance was discovered by Hungary as well. Thanks to this, there are more optimistic initiatives apart from Smart Grid trials previously introduced, which had no success. One of Hungary's most notable electric energy service providers, the EDF DÉMÁSZ ran a pilot project around Szeged with the supervision of the Hungarian National Energy Bureau, to evaluate the opportunities of importing the technological solution, its estimated costs, and also get a picture on how the civilians would accept such a project. During the programme christened "Smart Synergy Project", and its original 2012 run, nearly 3000 electric measurement devices were installed (500 of which used PLC, the remainder used GPRS technology), and 100-150 water- and gas-measurement devices were also planted at the designated clientele with an absolute experimental goal. The tests and questionnaires were concluded in 2014, according to which the following could be said [17]:

- Reading precision is $97-99 \%$ using the GSM technology, and only $96-98$ using the PLC technology.

- PLC devices were easy to install.

- The concentrator accepts the identical measurement device the easiest.

- The balance of measurement device+adapter+head end+system+SAP is hard to create.

- The minimal resistance of consumers could be perceived during the installation of the measurement devices.

- Water- and gas-measurement devices were complicated to install.

- Measurement device manufacturers handed in more advantageous costs for the tender than without it.

- Costs weren't as low as estimates in the prior studies.

These clearly show that though adapting the technology may encounter difficulties in some areas, it can be operated with a high precision, and generally the acceptance of consumers can also be said to be positive [18]. The more serious problem surfacing would be the usual one, meaning that the tender infrastructure is insufficient, which may also increase the total costs of the project.

The EDF DÉMÁSZ was not the only one to experiment with smart measurement systems, ELMÜ ÉMÁSZ also tried it as part of their "Smart Metering Multi Utility" pilot project. Its interesting facet is that 4 public facility systems were tested with it, which is unique in all of Europe - apart from ÉMÁSZ, the Capital Gasworks Company (FÖGÁZ), the Capital Water Company, and the Budapest District-heating Service Providing Company (FÖTÁV Co. Ltd.) were included in the project. Resulting from this partnership, not only 8000 electric energy measurement devices were installed until 2013, but 1000-1000 drinking water- and gas devices, followed by 500 heat measurement smart devices were also installed in Budapest and Pest county. Currently, they're still in the testing phase, and their most important goal is to amass experience on their usage, and on how efficiently the cooperation between public utility providers can be realised in advocating smart metering. 


\section{RESULTS AND RECOMMENDATIONS}

Based on the experiences of NER300, and the trends we can see in the European Union, the forecasts referring to NER400's basis show different results. On the one hand, from the perspective of renewable energy resources, it's advantageous to concentrate on what Hungary's greatest potential is, thermal energy in particular. One of the biggest disadvantages this has is that its actualisation is quite expensive, as we can see from how the substantial subsidies offered for the Dél-Alföld EGS project only covered one third of total costs. However, the financial resources multiplied many times, set for the next subsidy period offer a great opportunity to realise similar high-caliber visions. On the other hand, when we look at the modernisations currently happening in the Union, we also have to realise that before we plan producing new types of energy, and building new energy systems, we have to rethink their usage process. We have to inspect the creation of contradictory concepts, since while most member states are busy preparing their countries and its people for the next evolutionary step in energy usage, we're running pilot projects with scarce element numbers covering only a small, few-thousand clientele.

Naturally, this is a requirement for all high-profile projects, but we can't forget that in the case of committed member states actualising their development programmes, the few that didn't install smart measurement systems (one of which is Hungary) may have a serious detrimental effect on their competitiveness to deal with. Also, one of the most notable critiques formed against Hungary's currently advancing energy resource, namely, nuclear energy, is that it's hard to control the quantity of produced energy, and match it to hard-to-calculate consumer demands. From this perspective, the presence of smart measurement devices in Hungary may immediately have more appeal compared to other countries. To conclude the analysis, we can summarise that creating Smart Metering systems throughout the nation needs to have a high priority in future development plans, and we'll require the usage of subsidy funds like NER400 to actualise said plans.

\section{REFERENCES}

[1] Kovács I. (2013) A geotermia új lehetősége Magyarországon: helyzetkép az EGS projektről. Kutatás és Innováció a Geotermiában konferencia, Budapest, 2013 http://geotermia.lapunk hu/tarhelygeotermia/dokumentumok/kovacsimredr _eu_fire_eloadasa_20131030.pdf

[2] Ghassemi A. (2012): A Review of Some Rock Mechanics Issues in Geothermal Reservoir Development Geotechnical and Geological Engineering, June 2012, Vol. 30, Issue 3, pp. 647-664. DOI: 10.1007/s10706-012-9508-3

[3] Lupion M., Herzog J. H. (2013): NER300: Lessons learnt in attempting to secure CCS in Europe. International Journal of Greenhouse Gas Control, November 2013, Vol. 19, pp. 19-25. DOI: 10.1016/j.ijggc.2013.08.009

[4] DARby S. (2010): Smart metering: what potential for householder engagement? Building Research \& Information, Special Issue: Housing occupancy feedback: linking behaviours and performance, Vol. 38, Issue 5, pp. 442-457. DOI: $10.1080 / 09613218.2010 .492660$

[5] Farhangi H. (2010): The path of the smart grid. IEEE Power and Energy Magazine, Vol. 8, Issue 1, pp. 18-28. DOI: 10.1109/MPE.2009.934876

[6] Fogarassy C., Lukács A., Nagy H. (2008) Potential benefits of linking the Green Investment Scheme of the Kyoto Protocol with institutional voluntary markets like the Chicago Climate Exchange. In: ENVECON - UK Network of Environmental Economics Conference, London, 14 p.

[7] Fogarassy, C. (2014) The Interpretation of Sustainability Criteria using Game Theory Models (Sustainable project development with Rubik's Cube), Budapest; Paris: L' Harmattan Publisher, p.117 https://www.scribd.com/doc/250370912/Fogarassy-Rubik-Model-Eng-Harmattan-Publisher-2014

[8] Fogarassy C., Horvath B., Szoke L., Kovacs A. (2015) Low -carbon innovation policy with the use of bio-renewables in the transport sector until 2030. APSTRACT - Applied Studies in Agribusiness and Commerce Vol. 9. Issue 4. p. 45 DOI:10.19041/APSTRACT/2015/4/6 
[9] Granström P., Jackson J. A., Denda R., Gomez A., Perez J. A. R., Baron M., Micheli G.,

Cagno E., Mauri G., Goni A. (2014): Steering the implementation of smart metering solutions throughout Europe, Meter On $7^{\text {th }}$ Framework Programme of the European Commission project, Final report.

[10] European Commission (2014): Cost-benefit analyses \& state of play of smart metering deployment in the EU-27. (June 2014)

[11] Barzola J., Rubini L. (2014): The telegestore system evolved according OSI model and its performance compared with the new IEEE 1901.2 standard. Central America and Panama Convention (CONCAPAN XXXIV), 12-14 of November, 2014 IEEE. DOI: 10.1109/CONCAPAN.2014.7000448

[12] SöpERbrom J. (2012): Smart Meter roll-out experiences from Vattenfall - EURELECTRIC 2012. 12. 06

[13] RogaI S. (2007): Telegestore Project - Progress \& Results, IEEE ISPLC Conference, Pisa, $26^{\text {th }}$ March 2007

[14] Fiorelli R. (2011): Optimizing Field performance and Efficiency. Metering Billing/CRM Europe conference, $5^{\text {th }}$ of October, 2011, Amsterdam, 2013

[15] Vadacchino V., Denda R., Fantini G. (2013): First results in Endesa smart metering roll-out. Electricity Distribution (CIRED 2013), 22nd International Conference and Exhibition 10-13th of June, 2013, Stockholm. DOI:10.1049/cp.2013.0850

[16] Loum Alieu., Fogarassy C (2015) The effects of climate change on cereals yield of production and food security in Gambia. APSTRACT - Applied Studies in Agribusiness and Commerce 9:(4) pp. 90-92. DOI: $10.19041 /$ APSTRACT/2015/4/11

[17] NAGY I. (2013): Az okos mérés hatása a felhasználói tudatosságra. 50. MKT Vándorgyülés, 27 $7^{\text {th }}$ of September, 2012, Eger.

[18] Csaba Bálint Illés, Hilda Hurta, Anna Dunay (2015) Efficiency and Profitability Along the Lifecycle Stages of Small Enterprises. International Journal of Management and Enterprise Development 14:(1) pp. 56-57. (2015) https://www.scopus.com/record/display.uri?origin=inward\&eid=2-s2.0-84929232300\# 